\title{
VIABILITY STATUS OF DIABETES MELITUS PATIENTS WITH COMPLICATIONS OF HYPERGLYCEMIA, CETOASIDOSIS, AND GANGRENE
}

\section{Status Kelangsungan Hidup Penderita Diabetes Melitus Dengan Komplikasi Hiperglikemi, Ketoasidosis, dan Gangrene}

\author{
Norshinta Anggraini Putri ${ }^{1}$, Hari Basuki Notobroto ${ }^{2}$ \\ ${ }^{1}$ Faculty of Public Health, Universitas Airlangga, norshinta719@gmail.com \\ ${ }^{2}$ Department of Biostatistics and Population Studies, Faculty of Public Health, Universitas Airlangga, \\ haribasuki.n@fkm.unair.ac.id \\ Corresponding Author: Hari Basuki Notobroto, haribasuki.n@fkm.unair.ac.id, Department of Biostatistics and \\ Population Studies, Faculty of Public Health, Universitas Airlangga, Dr. Ir. H. Soekarno Street, Mulyorejo, \\ Surabaya City, East Java, 60115, Indonesia
}

\section{ARTICLE INFO \\ Article History: \\ Received June, $16^{\text {th }}, 2019$ \\ Revised form July, $15^{\text {th }}, 2019$ \\ Accepted January, $16^{\text {th }}, 2020$ \\ Published online January, $28^{\text {th }}, 2020$}

\author{
Keywords: \\ diabetes; \\ complications; \\ survival; \\ risk factors; \\ diet
}

\section{Kata Kunci: \\ diabetes; \\ komplikasi; \\ survival; \\ faktor risiko; \\ diet}

\begin{abstract}
Background: Indonesia ranked the seventh position of the most diabetes patients among other countries. Several risk factors affected the viability of Diabetes Mellitus (DM) patients, such as sex, age, type of DM, obesity, diet program, and family history of DM. Purpose: This research aims to analyze the variables that affect the viability of DM patients with complications. Methods: This research used descriptive analytic research with cross-sectional research design. The population used in this research was DM patients with complications (hyperglycemia, ketoacidosis, and gangrene) who were hospitalized at X Hospital in Madiun, which recorded in JanuaryDecember 2018. This research used a total sample with data obtainment techniques used medical records data sources of DM patients with complications (hyperglycemia, ketoacidosis, and gangrene) which recorded in January-December 2018 and observed until January 2019. The analysis technique used was survival analysis using kaplan meier, breslow, and cox regression. Results: The characteristics of respondents were the majority were 60 years old and over $(53.70 \%)$ and were female respondents $(63 \%)$. Based on the research results of several variables, only diet program variable which was significant among all independent variables $(\mathrm{p}=0.01 ; \mathrm{HR}=$ $3.74 ; 95 \% \mathrm{CI}=1.65<\mathrm{OR}<8.48$ ), which suspected to affect the viability of DM patients with complications (hyperglycemia, ketoacidosis, and gangrene). Conclusion: The most influential risk factor is diet program.
\end{abstract}

C2020 Jurnal Berkala Epidemiologi. Published by Universitas Airlangga. This is an open access article under CC-BY-SA license (https://creativecommons.org/licenses/by-sa/4.0/)

Notobroto, H. B. (2020). Viability status of diabetes melitus patients with complications of hyperglycemia, cetoasidosis, and gangrene. Jurnal Berkala Epidemiologi, $\quad 8(1), \quad 72-80$. https:/dx.doi.org/10.20473/ jbe.v8i12020.72-80

\section{ABSTRAK}

Latar Belakang: Indonesia menempati posisi ke tujuh dari sepuluh negara dengan penderita diabetes terbanyak. Beberapa faktor risiko yang mempengaruhi kelangsungan hidup penderita Diabetes Melitus (DM) seperti jenis kelamin, umur, tipe DM, obesitas, program diet, 
riwayat keluarga DM. Tujuan: Penelitian ini bertujuan untuk menganalisis variabel yang mempengaruhi kelangsungan hidup penderita DM dengan komplikasi. Metode: Penelitian ini menggunakan penelitian obervasional analitik deskriptif dengan desain penelitian cross sectional. Populasi yang digunakan dalam penelitian ini adalah penderita DM dengan komplikasi (hiperglikemi, ketoasidosis, dan gangrene) yang dirawat inap di Rumah Sakit $X$ Kota Madiun yang tercatat pada Januari-Desember 2018. Penelitian ini menggunakan total sampling dengan teknik pengambilan data berasal dari sumber data rekam medik penderita DM dengan komplikasi (hiperglikemi, ketoasidosis, dan gangrene) yang tercatat Januari-Desember 2018 dan diamati sampai Januari 2019. Teknik analisis yang digunakan yaitu menggunakan analisis survival dengan pendekatan kaplan meier, breslow, dan regresi cox. Hasil: Karakteristik responden adalah sebagian besar responden berumur 60 tahun keatas $(53,70 \%)$ dan berjenis kelamin perempuan (63\%). Berdasarkan hasil penelitian dari beberapa variabel, hanya variabel program diet yang signifikan diantara semua variabel independen $(p=0,01 ; H R=3,74 ; 95 \% C I=1,65<O R<8,48)$ yang diduga mempengaruhi kelangsungan hidup penderita DM dengan komplikasi (hiperglikemi, ketoasidosis, dan gangrene). Kesimpulan: Faktor risiko yang paling mempengaruhi adalah program diet.

C2020 Jurnal Berkala Epidemiologi. Penerbit Universitas Airlangga. Jurnal ini dapat diakses secara terbuka dan memiliki lisensi CC-BY-SA (https://creativecommons.org/licenses/by-sa/4.0/)

\section{INTRODUCTION}

Non-communicable diseases (NCD) had become a public health problem. The incidence of non-communicable diseases in 2004 was slightly higher $(48.30 \%)$ compared to communicable diseases (47.50\%), even non-communicable diseases were the first cause of death in the world $(63.50 \%)$. World Health Organization (WHO) stated that diabetes causes 1.50 million deaths in 2012. Death occurred before the age of 70 years and was higher in lower-middle-income countries than in high-income countries (Ministry of Health RI, 2014).

Diabetes mellitus (DM) is a balance disorder between the transportation of sugar into cells, sugar stored in the liver, and sugar released from the liver. This results in increased blood sugar levels and will be excreted in urine, so urine contains lots of sugar (diabetes) (Tandra, 2017).

Diabetes mellitus which is not handled properly will cause complications. This is because diabetes mellitus has a long-term damage effect that will result in reduced or damaged other organ functions. There are two complications in diabetes, namely acute and chronic. Acute diabetes is a sudden and fatal complication, while chronic diabetes is a complication that develops slowly along with the duration of diabetes and will develop to be fatal if it is not handled properly (Tandra, 2017). Research conducted by Utami, Karim, \& Agrina (2014) stated that diabetes mellitus patients with complications had a lower quality of life than diabetes mellitus patients without complications. In type 2 diabetes, patients are more susceptible to differences in short-term and long-term complications (Wu, Ding, Tanaka, \& Zhang, 2014).

Diabetes patients had an increased risk of complications such as stroke, myocardial infarction, and coronary artery disease, but some complications such as retinopathy, nephropathy, and neuropathy can adversely affect the quality of life of patients and a significant increase in financial burden (Sami, Ansari, Butt, \& Hamid, 2017).

The viability of diabetes mellitus patients can be affected by age, sex, type of DM, weight, diet, and the occurence of complications. The best and most affected models on the viability of diabetes patients are age, genetics, and diet (Rahayu, Setiawan, \& Mahatma, 2012).

Research conducted by Purwandari \& Susanti (2017) stated that there was a fairly strong relationship between diet adherence and good 
quality of life in diabetes mellitus patients at Kertosono Regional Hospital.

Patients with obesity had risk of developing type 2 diabetes mellitus. Fat in the body can inhibit the entry of sugar in the blood into the body's cells, consequently sugar piled up in the blood (Tandra, 2017).

According to the International Diabetes Federations (IDF) for the first time estimated that there are more than half a million children aged 14 years who suffer from type 1 diabetes. The estimation in 2015 was there were 415 million people aged 20-79 years with diabetes, including 193 million undiagnosed, and by the end of 2015, there were 5.00 million deaths due to diabetes (IDF, 2015). WHO estimated that in 2014, there were 422 million adults aged $>18$ years lived with diabetes mellitus. About half of the cases of diabetes mellitus in the world were estimated to come from Southeast Asia and the Western Pacific (Ministry of Health RI, 2014).

Indonesia ranked the seventh of the top ten countries of adult diabetes patients with 10 million people of diabetics (IDF, 2015). Based on the health profile of Madiun in 2017, diabetes mellitus was in the third position of the ten most diseases in Madiun. There were 15,034 cases of type 1 and 2 diabetes mellitus in Madiun (Madiun City Health and Family Planning Office, 2017). Based on data at X Hospital of Madiun City during 2018, there were 122 inpatients, 54 of whom were patients with complications of hyperglycemia, ketoacidosis, and gangrene.

Because of the number of diabetes mellitus patients with complications, the researchers want to examine how the viability of diabetes mellitus patients with complications of hyperglycemia, ketoacidosis, and gangrene. Research subjects obtained from these three types of complications because at X Hospital of Madiun, the most cases of death of diabetes mellitus patients are diabetes patients with these three types of complications.

The aim of this research is to analyze factors related to the viability of diabetes mellitus patients with complications of hyperglycemia, ketoacidosis, and gangrene or based on the test to be used, that is to find out the right model on the viability of diabetes mellitus patients with complications.

\section{METHODS}

The type of research used was a cross sectional design. The population in this research were all diabetes patients with complications (hyperglycemia, ketoacidosis, and gangrene) who were hospitalized at X Hospital in Madiun and recorded in January 2018 to December 2018. The research used total sampling. The analytical method used was survival analysis using Cox regression. The variables used in this research consisted of the independent variables and the dependent variables. The independent variable consisted of affecting factors namely gender, age, family history of diabetes, participation in a diet program held by the hospital, obesity (BMI> 27), and type of diabetes. The dependent variable consisted of the length of time from the beginning of the observation until the event appeared, and the patient's status of life or death, where the status of life as a sensor and death as an event. Time of failure (death) if it occurred before the time of the research began, or death occurred after the time of the research was completed and the patients were still alive, then the data would be censored.

Time : viability from initial admissed of hospitalization to the occurrence of event day

Status : Death $($ event $)=1$, life $($ sensor $)=0$

In survival analysis, there was a survival function to define the probability of an individual to be able to live after a specified time. If $\mathrm{T}$ was the viability of an individual until an event occurs, then the equation of survival function was written as follows:

$S(t)=\operatorname{Pr}(T>t)$

The hazard function equation for defining failure rates was:

$$
h(t)=\lim _{\Delta t \rightarrow 0} \frac{P(t<T<t+\Delta t \mid T>t)}{\Delta t}
$$

Variable analysis used the cox regression test to find out which model or variable exactly affected the viability of diabetes mellitus patients with complications (hyperglycemia, ketoacidosis, and gangrene). The analysis process phase was carried out by recapitulating secondary data of diabetes mellitus patients with complications (hyperglycemia, ketoacidosis, and gangrene), identifying the variables used, and making a category of each independent variable taken.

Descriptive statistics of diabetes mellitus patients with complications (hyperglycemia, ketoacidosis, and gangrene) was by the Kaplan Meier test approach. Determination of the model estimation was by the Breslow approach. 
Processing the results of the model estimation used one of the computer application programs to obtain the Cox regression equation model, then interpreted the results and conclusions.

\section{RESULTS}

Distribution based on Characteristics of Diabetes Patients with Complications (Hyperglycemia, Ketoacidosis, and Gangrene) on January 2018 - December 2018

The majority of diabetes mellitus patients with complications (hyperglycemia, ketoacidosis, and gangrene) were females (63\%). Patients with no family history of DM were more at $61.10 \%$. The majority of patients joined a diet program at $70.40 \%$. Most patients were not obese at $63.00 \%$ and the majority of respondents as patients of type 2 diabetes mellitus at $66.70 \%$. The majority of patients were in the age group of older people or more than 60 years (Table 1 ).

\section{Analysis of Variables that Affected the Viability} Diabetes Mellitus Patients with Complications (Hyperglycemia, Ketoacidosis, and Gangrene)

The results of the estimation of Breslow test of gender variables showed that the age, gender, type of diabetes mellitus, obesity, and family history of diabetes mellitus were not significant. In the Breslow analysis, it was known that the variable included in the Cox regression estimation model was only diet program variable because the p-value $<0.05$, so the estimation assumption could be accepted (Table 2).

The results of calculations using the Kaplan Meier test, showed a mean survival value at 7.19 and a median survival at 7.00 . This meant that $50 \%$ of subjects had died within seven days. Based on the median survival variable category, male patients faster than females, the absence of a history of DM median survival was lower than that of a history of DM. Patients who did not join the diet program had a lower survival median than patients who joined the diet program. Both patients with obesity or not had the same survival median. In addition, patients with type 1 diabetes had a lower median survival. Furthermore, patients in the age group of 40-49 years had lower median survival than other age groups (Table 2).
Table 1

Frequency Distribution of Diabetes Mellitus Patients with Complications (Hyperglycemia, Ketoacidosis, and Gangrene) at X Hospital in Madiun City in 2018 based on Independent Variables

\begin{tabular}{lrr}
\hline \multicolumn{1}{c}{ Variable } & $\begin{array}{c}\text { Frquency } \\
(\mathrm{n})\end{array}$ & $\begin{array}{c}\text { Percentage } \\
\%\end{array}$ \\
\hline Gender & & \\
Male & 20 & 37.00 \\
Female & 34 & 63.00 \\
Family History DM & & \\
$\quad$ Yes & 21 & 38.90 \\
$\quad$ None & 33 & 61.10 \\
Diet Program & & \\
Yes & 38 & 70.40 \\
No & 16 & 29.60 \\
Obesity & & \\
Yes & 20 & 37.00 \\
No & 34 & 63.00 \\
DM Type & & \\
Type 1 & 18 & 33.30 \\
Type 2 & 36 & 66.70 \\
Age (years) & & \\
$\quad$ 40 & 3 & 5.60 \\
$40-49$ & 6 & 11.10 \\
50-59 & 16 & 29.60 \\
$\geq 60$ & 29 & 53.70 \\
\hline Total & 54 & 100.00 \\
\hline
\end{tabular}

Table 2

Median Survival and Breslow

\begin{tabular}{lrr}
\hline \multicolumn{1}{c}{ Variable } & Median (day) & Breslow \\
\hline Gender & 6 & 0.39 \\
Male & 7 & \\
Female & & \\
Family History DM & 9 & .86 \\
Yes & 7 & \\
None & & \\
Diet Program & 9 & 0.00 \\
Yes & 3 & \\
No & & \\
Obesity & 7 & 0.41 \\
Yes & 7 & \\
No & & \\
DM type & 6 & 0.33 \\
Type 1 & 9 & \\
Type 2 & & \\
Age (years) & 6 & \\
$<40$ & 3 & 0.68 \\
$40-49$ & 12 & \\
$50-59$ & 7 & \\
$\geq 60$ & & \\
\hline
\end{tabular}


In testing using Cox regression, there is only one variable that can be analyzed based on the results of the Breslow calculation. Based on these results, the following model obtained is:

$$
h(t)=h_{0}(t) e^{1220 \mathrm{det}}
$$

The results showed that diet has a value of $\mathrm{p}$ $=0.001$ with $\mathrm{HR}=3.74 ; 95 \%$ CI $1.65-8.48$. It means that there is an influence of dietary program variable with viability of diabetic patients with complications (hyperglycemia, ketoacidosis, and gangrene). Patients who did not do dietary program were 3.74 times more at risk of dying than those who did dietary program (Table 3 ).

\section{DISCUSSION}

\section{Characteristics of Diabetics with Complications (Hyperglycemia, Ketoacidosis, and Gangrene)}

Most diabetes mellitus patients with complications (hyperglycemia, ketoacidosis, and gangrene) who were hospitalized were in the age group $\geq 60$ years. It is in line with Meidikayanti \& Wahyuni's research (2017) which stated that the majority of respondents were in the elderly age group or $\geq 60$ years about 27 respondents $(54 \%)$. These results are in accordance with research by Kistianita, Yunus, \& Gayatri (2015) which stated that the majority of patients were in the 55-64 years age group (75\%). Research by Isnaini \& Ratnasari (2018) also mentioned similar results that the majority of respondents were aged $\geq 45$ years $(83 \%)$. This is also in accordance with Widyasari's research (2017) which stated that there was a relation between age and diabetes mellitus status and dyslipidemia status. In old age, a person will be more vulnerable with high diabetes status and high dyslipidemia attacks. In general, degenerative diseases occur in older people, because when a person gets older some cell functions will decrease. This is in accordance with the characteristics of patients who are mostly at the age of $\geq 60$ years or can be categorized as elderly.

The majority of diabetes mellitus patients with complications (hyperglycemia, ketoacidosis, and gangrene) who were hospitalized were females. These results are in line with Widyasari's research (2017) which stated that the majority of female respondents were around 38 respondents $(76 \%)$. Moreover, it is also in accordance with the research of Amoussou-guenou et al (2015) which stated that the distribution of diabetes mellitus patients in females was $6.80 \%$.

Research conducted by Juanita \& Safitri (2016) stated that the majority of female respondents were as many as $27(54 \%)$. These results are different from the study of Obunikem et al (2015) which stated that most of the respondents studied were male as many as $52.10 \%$.

Gender categorization in diabetes patients with complications was done to differentiate the results of diagnosis and therapy to do. The proportion of deaths in Africa, Europe, the Middle East, North Africa, Southeast Asia, South and Central America, due to diabetes mellitus is higher in women than men. This might be due to men having higher mortality due to other diseases (IDF, 2015).

\section{Risk Factors for Family History in Diabetes Mellitus Patients with Complications (Hyperglycemia, Ketoacidosis, and Gangrene)}

The results showed that most patients with diabetes mellitus with complications (hyperglycemia, ketoacidosis, and gangrene) who were hospitalized, had no family history of diabetes before. This result is in line with the research cunducted by Isnaini \& Ratnasari (2018) where the majority of research respondents did not have a family history of diabetes mellitus by $52.80 \%$ or 28 respondents. These results are also in line with the research conducted by Noh et al (2018) which stated that most diabetics did not have a family history of diabetes mellitus.

Table 3

Cox Regression Test Results

\begin{tabular}{|c|c|c|c|c|c|c|c|c|c|}
\hline \multirow{3}{*}{ Diet Program } & \multicolumn{4}{|c|}{ Failure } & \multirow{2}{*}{\multicolumn{2}{|c|}{ Total }} & \multirow{3}{*}{$p$} & \multirow{3}{*}{ B } & \multirow{3}{*}{$\begin{array}{l}\text { HR value } \\
(95 \% \mathrm{CI})\end{array}$} \\
\hline & \multicolumn{2}{|c|}{ Yes } & \multicolumn{2}{|c|}{ No } & & & & & \\
\hline & $\mathrm{n}$ & $\%$ & $\mathrm{n}$ & $\%$ & $\mathrm{n}$ & $\%$ & & & \\
\hline Yes & 15 & 27.80 & 23 & 42.60 & 38 & 29.60 & 0.00 & 1.32 & 3,744 \\
\hline No & 12 & 22.20 & 4 & 7.40 & 16 & 70.40 & & & $(1.65<\mathrm{HR}<8.48)$ \\
\hline Total & 27 & 50.00 & 27 & 50.00 & 54 & 100.00 & & & \\
\hline
\end{tabular}


Based on the results of this research, it is known that diabetes mellitus patients with complications (hyperglycemia, ketoacidosis, and gangrene) who do not have a family history of diabetes mellitus have a shorter viability than diabetics patients with a family history of diabetes mellitus. These results are different from the research by Noh et al (2018) which stated that diabetics who had a family history of diabetes mellitus had a lower viability than diabetics patients who had no family history of diabetes mellitus.

Risk factors for type 1 diabetes mellitus are usually caused by family history of diabetes mellitus or genetic, whereas risk factors for type 2 diabetes mellitus are related to the behavior or lifestyle of the patients, such as being overweight or obese. Type 2 diabetes can also be caused by other risk factors such as family history of diabetes mellitus (IDF, 2015). The risk of suffering from diabetes type 2 increases with increasing age, obesity, and lack of physical activity. It often happens in female with a history of gestational diabetes mellitus before, patients with hypertension or dyslipidemia, and in subgroups of race/ethnicity particulary as African American, American Indian, Hispanic/Latino, and Asian American. It is often associated with a strong genetic predisposition or family history in first level relative, however, the influence of genetics in diabetes type 2 patients are yet to be understood (American Diabetes Center, 2018).

\section{Dietary Program Factors in Diabetes Mellitus Patients with Complications (Hyperglycemia, Ketoacidosis, and Gangrene) \\ The results showed that the majority of} diabetes mellitus patients with complications (hyperglycemia, ketoacidosis, and gangrene ) who were hospitalized followed a diet program (70.40\%). It is in accordance with the research conducted by Hestiana (2017) which stated that the majority of respondents dutifully following a diet program that was as many as 29 respondents.

Based on the results of the research, it is known that diabetes patients with complications who do not go on a diet have a lower viability than diabetes patients with complications who go on a diet. There is only 4 people of patients who do not follow the diet program. This is due to the diet carried out is to prevent and delay the development of diabetes mellitus. The research of $\mathrm{n}$ Piłaciński \& Zozulińska-Ziółkiewicz (2014) stated that lifestyle changes in diabetes mellitus patients could have a beneficial effect on viability.
Piłaciński \& Zozulińska-Ziółkiewicz (2014) also mentioned that eating disorders were associated with poor metabolic control and decreased survival in people with type 1 diabetes mellitus, with an increased risk of diabetes ketoacidosis and chronic complications from diabetes.

Reduction in calorie intake is very important for those who has high risk against the onset of diabetes type 2, although the latest evidence shows that the quality of the fats that are consumed in the diet is more important than the number of total fat consumed (American Diabetes Center, 2018). Based on intervention research on food, nutritional therapy and lifestyle changes are the early recommendations for initial treatment of dyslipidemia. Metabolic control is considered a cornerstone in diabetes management and its complications (Sami, Ansari, Butt, \& Hamid, 2017).

In the analysis phase, it is known that dietary variables are factors that can be used in the Cox regression test and form a model. The results showed that there was an influence between the diet program on the viability of diabetes mellitus patients with complications (hyperglycemia, ketoacidosis, and gangrene). The results also showed that diabetes mellitus patients with complications (hyperglycemia, ketoacidosis, and gangrene) who were hospitalized and did not go on a diet program were 3.74 times more likely to die than patients on diet. According to Hestiana's research (2017), it stated that in doing a diet program, both male and female, was very important to manage the diet in order to prevent complications.

The pattern of diet affects the amount of insulin needed to meet the target blood glucose to sustain the optimal levels of blood glucose. Diet patterns, especially carbohydrate intake, can contribute to the pathology of diabetes (Fareed, Salam, Khoja, Abdulrahman, \& Ahamed, 2017).

\section{Obesity Factors in Diabetes Mellitus Patients with Complications (Hyperglycemia, Ketoacidosis, and Gangrene)}

The study showed the results that most diabetes mellitus patients with complications (hyperglycemia, ketoacidosis, and gangrene) who were hospitalized were not obese as many as 34 patients $(63 \%)$. In contrast to Widyasari's research (2017) which stated that the majority or almost all respondents with diabetes mellitus were obese.

The results showed that the viability of diabetes mellitus patients with obesity and nonobesity have the same viability period. These 
results are in contrast to research by Teni, Enquoselassie, \& Atsmegiorgis (2015) which stated that there was a difference in viability period of diabetes patients with excess body weight or not. The outcome of diabetes patients with excess body weight was having lower viability period than patients with ideal body weight.

Most research have discussed the strong relation of obesity with overeating which leads to the incidence of type 2 diabetes mellitus (Sami, Ansari, Butt, \& Hamid, 2017). The research of Stanifer et al (2016) stated that being overweight or obese was an independent risk factor for glucose disorders. It's proven by the analysis that showed the increased risk of prevalence (PR 2, 16; 95\% CI 1.39 to 3.36) compared to individuals with ideal body weight.

Lifestyle changes in some patients with obesity or excess body weight with type 2 diabetes as well as other medical conditions related to obesity, showing the simple and continuous weight loss which can decrease the levels of blood glucose, HbAlc (Hemoglobin A1c or glycohemoglobin), and triglycerides which clinically significant (American Diabetes Center, 2018).

In diabetes patients who are overweight or obese, the degree of insulin resistance is caused by obesity itself (Fareed, Salam, Khoja, Abdulrahman, \& Ahamed, 2017). Comorbidities of type 1 diabetes are autoimmune diseases such as thyroiditis and celiac, whereas in type 2 diabetes are visceral obesity and hypertension or also called metabolic (Petersmann et al., 2018).

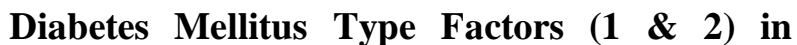
Diabetes Mellitus Patients with Complications (Hyperglycemia, Ketoacidosis, and Gangrene)

The results showed that the majority of diabetes mellitus patients with complications (hyperglycemia, ketoacidosis, and gangrene) were 36 patients with type 2 diabetes. The research also showed that patients of type 2 diabetes is most likely to survive than patients with type 1 diabetes. This is likely to occur because of the frequent complications that arise in type 1 diabetes mellitus is acute. These results are in line with the research of Teni, Enquoselassie, \& Atsmegiorgis (2015) which stated that people with type 1 diabetes mellitus had a lower viability than patients with type 2 diabetes mellitus with complications.

Autoimmune is a comorbidity of type 1 diabetes mellitus (Petersmann et al., 2018). Viruses are an important driver for the pathogenesis of type 1 diabetes mellitus. Increased incidence of type 1 diabetes mellitus occurs in children who have a history of exposure to rubella during pregnancy, but it also can be caused by other triggers, such as autoimmune interference (Paschou, Papadopoulou-marketou, Chrousos, \& Kanaka-Gantenbein, 2018).

Complications that arise in patients with type 2 diabetes mellitus are caused by poor treatment. The most complications of type 2 diabetes mellitus arise in microvascular and macrovascular problems (Fareed, Salam, Khoja, Abdulrahman, \& Ahamed, 2017).

Type of diabetes mellitus classification is important to be done to determine the therapy. However, most people are not able to be classified clearly whether having type 1 or 2 diabetes at the time when diagnosed. Long paradigm diabetes mentioned type 2 which only occurs in the adult and diabetes type 1 only on children is no longer appropriate, because both diseases occur in both groups of age now (American Diabetes Center, 2018).

\section{Research Limitations}

Limitations of the study are only respondents who experienced complications of hyperglycemia, ketoacidosis, and gangrene. This is because the data is based on the medical record data of diabetic patients only with these complications recorded in the hospital medical record.

\section{CONCLUSION}

There is influence of diet program variable with viability of diabetes mellitus patients with complications of hyperglycemia, ketoacidosis, and gangrene. Meanwhile, there is no influence between variables of gender, age, family history of DM, obesity, and type of DM with the viability of diabetes mellitus patients.

\section{CONFLICT OF INTEREST}

The authors declare that no conflict of interest in this study.

\section{ACKNOWLEDGMENT}

Thank you to X Hospital in Madiun City who has given permission for doing research and also the assistance that has been given by medical records officers in data collection. 


\section{REFERENCES}

American Diabetes Center. (2018). Standards of medical care in diabetes-2018. The Journal of Clinical and Applied Research Adn Education: Diabetes Care, 41(Supplement 1), $1-150$.

Amoussou-guenou, A., Armand, W., Michel, H., Anthelme, A., Marius, B., Amoussouguenou, F. A., \& Annelie, K. (2015). Prevalence and risk factors of diabetes mellitus in the adult population of PortoNovo (Benin). Journal of Diabetes Mellitus, 5(3), 135-140.

Fareed, M., Salam, N., Khoja, A. T., Abdulrahman, M., \& Ahamed, M. (2017). Life style related risk factors of type 2 diabetes mellitus and its increased prevalence in Saudi Arabia: a brief review. International Journal of Medical Research \& Health Sciences, 6(3), 125-132.

Fatimah, R. N. (2015). Diabetes melitus tipe 2. Jurnal Majority, 4(5), 93-101.

Hestiana, D. W. (2017). Faktor-faktor yang berhubungan dengan kepatuhan dalam pengelolaan diet pada pasien rawat jalan diabetes mellitus tipe 2 di Kota Semarang. Journal of Health Education, 2(2), 138-145.

IDF. (2015). IDF diabetes atlas (7th ed.). Retrieved from www.diabetesatlas.org

Isnaini, N., \& Ratnasari. (2018). Faktor risiko mempengaruhi kejadian diabetes mellitus tipe dua. Jurnal Keperawatan Dan Kebidanan Aisyiyah, 14(1), 59-68.

Juanita, \& Safitri, C. P. (2016). Hubungan basic conditioning factors dengan kualitas hidup lanjut usia dengan diabetes melitus id RSUD Dr. Zainoel Abidin Banda Aceh. Idea Nursing Journal, 7(1), 48-60.

Kistianita, A. N., Yunus, M., \& Gayatri, R. W. (2015). Analisis faktor risiko diabetes mellitus tipe 2 pada usia produktif dengan pendekatan WHO stepwise step 1(core/inti) di Puskesmas Kendalkerep Kota Malang. Preventia: The Indonesian Journal of Public Health, 3(1), 1-14.

Madiun City Health and Family Planning Office. (2017). Madiun City health profile 2017. Madiun City. Madiun City Health and Family Planning Office.

Meidikayanti, W., \& Wahyuni, C. U. (2017). The correlation between family support with quality of life diabetes mellitus type 2 in Pademawu PHC. Jurnal Berkala Epidemiologi, 5(2), 240-252. https://doi.org/10.20473/jbe.v5i2.2017.240252

Ministry of Health RI. (2014). Infodatin: Indonesia situation and analysis of diabetes. Jakarta: Ministry of Health RI.

Noh, J., Jung, J. H., Park, J. E., Lee, J. H., Sim, K. H., Park, J., ... Yoo, K. (2018). The relationship between age of onset and risk factors including family history and life style in Korean population with type 2 diabetes mellitus. The Journal of Physical Therapy Science, 30(2), 201-206.

Obunikem, P., Adogu, U., Chineke, H. N., Ewuzie, M. U., Enwere, O. O., \& Egenti, N. B. (2015). The prevalence and presentation pattern of diabetes mellitus in patients at Imo State University Teaching Hospital (IMSUTH) Orlu and Imo State Specialist Hospital (IMSSH) Umuguma Owerri (a 10year retrospective study: 1st November 2004 to 31 st October. Journal of Diabetes Mellitus, 5(2), 49-57.

Paschou, S. A., Papadopoulou-marketou, N., Chrousos, G. P., \& Kanaka-Gantenbein, C. (2018). On type 1 diabetes mellitus pathogenesis. Endocrine Connections, 7(1), $38-46$.

Petersmann, A., Nauck, M., Müller-wieland, D., Kerner, W., Müller, U. A., Landgraf, R., ... DGKL. (2018). Definition, classification and diagnostics of diabetes mellitus. Experimental \& Clinical Endocrinology \& Diabetes: Official Journal of German Society of Endocrinology \& German Diabetes Association, 126(7), 406-410. https://doi.org/10.1055/a-0584-6223. Epub 2018 Jul 5.

Piłaciński, S., \& Zozulińska-Ziółkiewicz, D. A. (2014). Influence of lifestyle on the course of type 1 diabetes mellitus. Archive of Medical Science, 10(1), 124-134.

Purwandari, H., \& Susanti, S. N. (2017). Hubungan kepatuhan diet dengan kualitas hidup pada penderita DM di Poli Penyakit Dalam RSUD Kertosono. STRADA Jurnal Ilmiah Kesehatan, 6(2), 16-21.

Rahayu, N., Setiawan, A., \& Mahatma, T. (2012). Analisis regresi cox proportional hazards pada ketahanan hidup pasien diabetes mellitus. In P. Widyaningsih, Respatiwulan, S. Kuntari, N. A. Kurdhi, \& B. Winarno (Eds.), Seminar Nasional Matematika. Surakarta: Universitas Sebelas Maret Surakarta.

Sami, W., Ansari, T., Butt, N. S., \& Hamid, M. R. 
A. (2017). Effect of diet on type 2 diabetes mellitus : a review. International Journal of Health Sciences, 11(2), 65-71.

Stanifer, J. W., Cleland, C. R., Makuka, G. J., Egger, R., Maro, V., Maro, H., ... Philippin, H. (2016). Prevalence, risk factors, and complications of diabetes in the Kilimanjaro Region: a population-based study from Tanzania. PLoS ONE, 11(10), 1-13. https://doi.org/10.1371/journal.pone.0164428

Tandra, H. (2017). Segala sesuatu yang harus anda ketahui tentang Diabetes. Indonesia: Gramedia Pustaka Utama.

Teni, D. A., Enquoselassie, F., \& Atsmegiorgis, C. (2015). Survival analysis of diabetes mellitus patients using parametric, non-parametric and semi-parametric approaches: Addis Ababa , Ethiopia. Ethiopian E-Journal for Research and Innovation Foresight, 7(1), 20-39.

Utami, D. T., Karim, D., \& Agrina. (2014). Faktor-faktor yang mempengaruhi kualitas hidup pasien diabates mellitus dengan ulkus diabetikum. JOM PSIK, 1(2), 1-7.

Widyasari, N. (2017). Relationship of respondents's characteristic with the risk of diabetes mellitus and dislipidemia at Tanah Kali Kedinding. Jurnal Berkala Epidemiologi, 5(1), 130-141. https://doi.org/10.20473/jbe.v5i1.

Wu, Y., Ding, Y., Tanaka, Y., \& Zhang, W. (2014). Risk factors contributing to type 2 diabetes and recent advances in the treatment and prevention. International Journal of Medical Sciences, 11(11), 1185-1200. https://doi.org/10.7150/ijms.10001 